\title{
Influence of selected species of monocotyledonous weeds on the germination and early growth of spring barley (Hordeum vulgare)
}

\author{
Wpływ wybranych gatunków chwastów jednoliściennych na kiełkowanie \\ i początkowy wzrost jęczmienia jarego (Hordeum vulgare)
}

\author{
Marcin Bortniak*, Katarzyna Marczewska-Kolasa, Tomasz Sekutowski, Krzysztof Domaradzki
}

\begin{abstract}
Summary
The aim of the laboratory research, was to evaluate an influence of three monocotyledon weed species (Echinochloa crus-galli, Setaria pumila and Avena fatua) on the germination and early growth of spring barley (Hordeum vulgare) using a II generation biotest - Phytotoxkit ${ }^{\mathrm{TM}}$. The obtained results did not show any univocal allelopathic (inhibitory or stimulatory) effect of E. crus-galli, S. pumila and $A$. fatua caryopses on germination of spring barley. However, root length and fresh biomass of roots, as well as coleoptile of spring barley were affected. The weed species and number of weed seeds placed in close vicinity to spring barley caryopses were the factors differentiating inhibitory or stimulatory effect. A stimulatory influence was recorded only at the lowest density of S. pumila and E. crusgalli seeds ( 5 units/spring barley caryopsis) in correlation to a fresh root biomass, as well as root length and fresh coleoptile biomass of spring barley. The presence of S. pumila and E. crus-galli seeds significantly reduced root length and fresh biomass of coleoptile of spring barley, but only at the highest density (20 units/spring barley caryopsis). The strongest inhibitory allelopathic potential effect on the initial growth of spring barley was found for $A$. fatua caryopses. As small amount as 2 units/spring barley caryopsis reduced a root length reduction, while the presence of $A$. fatua, at 3 and 5 units per spring barley caryopsis, significantly inhibited root length and fresh root biomass, as well as fresh coleoptile biomass of spring barley.
\end{abstract}

Key words: allelopathic potential; spring barley; seeds; germination; biometric parameters; monocotyledonous weeds

\section{Streszczenie}

W badaniach laboratoryjnych przeprowadzonych z użyciem biotestu II generacji - Phytotoxkit ${ }^{\mathrm{TM}}$, porównywano wpływ trzech gatunków nasion chwastów jednoliściennych (Echinochloa crus-galli, Setaria pumila oraz Avena fatua) na kiełkowanie i początkowy wzrost jęczmienia jarego. Uzyskane wyniki badań nie wykazały jednoznacznego allelopatycznego oddziaływania (inhibicyjnego czy stymulującego) ziarniaków E. crus-galli, S. pumila i A. fatua na kiełkowanie jęczmienia jarego. Stwierdzono natomiast takie oddziaływanie w odniesieniu do długości i świeżej masy korzeni i koleoptyla jęczmienia jarego. Czynnikami różnicującymi działanie inhibicyjne lub stymulujące były gatunki chwastów oraz liczba nasion tych chwastów zlokalizowana w bliskim sąsiedztwie ziarniaków jęczmienia jarego. Efekt stymulujący uzyskano jedynie przy najmniejszym zagęszczeniu (5 szt./ziarniak jęczmienia jarego) nasion S. pumila i E. crus-galli w odniesieniu do świeżej masy korzeni oraz długości i świeżej masy koleoptyla jęczmienia jarego. Obecność 20 sztuk nasion S. pumila i E. crus-galli powodowała istotną redukcję długości korzeni i koleoptyla jęczmienia jarego. Natomiast najsilniejszy inhibicyjny potencjał allelopatyczny, na początkowy wzrost jęczmienia jarego, wykazano dla ziarniaków A. fatua, gdyż już 2 szt./ziarniak jęczmienia jarego powodowały redukcję długości korzeni, a obecność $A$. fatua w liczbie 3 i 5 sztuk na ziarniak jęczmienia jarego istotnie hamowała długość i świeżą masą korzeni oraz długość i świeżą masę koleoptyli jęczmienia jarego.

Słowa kluczowe: potencjał allelopatyczny; jęczmień jary; nasiona; kiełkowanie; cechy biometryczne; chwasty jednoliścienne

Instytut Uprawy Nawożenia i Gleboznawstwa - Państwowy Instytut Badawczy w Puławach

Zakład Herbologii i Technik Uprawy Roli

Orzechowa 61, 50-540 Wrocław

*corresponding author: m.bortniak@iung.wroclaw.pl 


\section{Wstęp / Introduction}

Między- i wewnątrzgatunkowe oddziaływanie roślin poprzez wydzielanie związków chemicznych (allelopatyn) jest powszechnym zjawiskiem, występującym zarówno w ekosystemach naturalnych, jak i kontrolowanych, tj. agrofitocenozy. Rośliny wydzielające związki allelochemiczne, określane są mianem donorów, natomiast organizmy z nią sąsiadujące i narażone na działanie tych substancji nazywane są akceptorami. Efekty takich interakcji mogą mieć charakter stymulacyjny lub inhibicyjny. Bywa, że związki stymulujące, występujące w wysokich stężeniach mogą działać hamująco, a związki będące inhibitorami, w niskich stężeniach mogą pobudzać niektóre procesy życiowe akceptora (Gniazdowska i wsp. 2004).

Organami najzasobniejszymi w substancje allelopatyczne są liście, w następnej kolejności korzenie, a najmniej znajduje się ich w nasionach i owocach. Wiele doniesień literaturowych wskazuje jednak, że substancje zawarte w okrywach nasion łatwo przenikają do gleby i mogą odgrywać istotną rolę $\mathrm{w}$ interakcjach pomiędzy gatunkami (Suman i wsp. 2002; Majchrzak 2007; Marczewska-Kolasa i wsp. 2010; Ghafarbi i wsp. 2012). Potencjat allelopatyczny nasion związany jest z zawartością licznych substancji np. kwasów fenolowych u zbóż. Kontrolują one kiełkowanie i początkowy wzrost zbóż poprzez narzucenie spoczynku bezwzględnego (Gniazdowska i wsp. 2004) oraz zabezpieczają je przed niekorzystnym wpływem czynników zewnętrznych (Vyvyan 2002).

W agrofitocenozie, allelopatycznie aktywne wydzieliny różnych gatunków chwastów odgrywają istotną rolę w dwóch głównych interakcjach, tj. chwast-chwast oraz chwast-roślina uprawna, przyczyniając się tym samym do sukcesu inwazyjnego niektórych gatunków (de Albuquerque i wsp.2011). Wielu autorów zauważa ogromny potencjał w wykorzystaniu allelopatyn jako naturalnych herbicydów lub jako komponentów pozwalających na zmniejszenie dawek syntetycznych herbicydów (Vyvyan 2002; Jabran i wsp. 2010; Kong 2010; Sekutowski 2010; Bhadoria 2011; Narwal i Haouala 2011; Khalaj i wsp. 2013).

Celem badań była ocena wpływu trzech gatunków chwastów jednoliściennych: Echinochloa crus-galli, Setaria pumila oraz Avena fatua na kiełkowanie i początkowy wzrost jęczmienia jarego.

\section{Materiały i metody / Materials and methods}

Doświadczenie przeprowadzono za pomocą zmodyfikowanego mikrobiotestu II generacji - Phytotoxkit ${ }^{\mathrm{TM}}$, produkcji belgijskiej firmy MicroBioTest Inc., umożliwiającego utrzymanie stałej temperatury na poziomie $25^{\circ} \mathrm{C}$, w czasie trwania eksperymentu (Phytotoxkit 2004). Badania wykonano w 3 niezależnych seriach (każda po 3 powtórze- nia), w 2-tygodniowych odstępach czasowych. W doświadczeniu wykorzystano ziarniaki trzech gatunków chwastów (E. crus-galli, S. pumila i A. fatua), pozyskane z pól uprawnych południowo-zachodniej Polski, które stanowią kolekcję zakładowego banku nasion chwastów.

Płytki testowe mikrobiotestu Phytotoxkit ${ }^{\mathrm{TM}}$ wypełniono wyprażonym wcześniej $\mathrm{w}$ temperaturze $105^{\circ} \mathrm{C}$ piaskiem, o średnicy ziaren $0,6-0,8 \mathrm{~mm}$, który nasączono $25 \mathrm{ml}$ wody destylowanej. Następnie płytki testowe przykryto specjalnym papierowym filtrem, na powierzchni którego wyłożono ziarniaki jarej formy jęczmienia (Hordeum vulgare) odmiany Conchita $\mathrm{w}$ ilości 5 szt./płytkę testową. $\mathrm{Na}$ tak przygotowane płytki, wysiano po 5,10 i 20 szt. ziarniaków E. crus-galli i S. pumila na każdy ziarniak jęczmienia jarego. W przypadku dużych ziarniaków A. fatua, wysiano mniejszą ich ilość: 2, 3 i 5 szt. na każdy ziarniak zboża. Obiekt kontrolny stanowiły płytki z ziarniakami jęczmienia jarego wysianymi samodzielnie (bez obecności donorów).

Przygotowane w ten sposób płytki testowe inkubowano w pozycji pionowej, w temperaturze $25^{\circ} \mathrm{C}$, bez dostępu światła. W trakcie trwania doświadczenia, analizowano dynamikę kiełkowania ziarniaków jęczmienia jarego, po 24, 48, 72 i 96 h od momentu założenia testu. Po $96 \mathrm{~h}$ dokonano rejestracji obrazu płytek testowych przy pomocy aparatu cyfrowego. Uzyskany w ten sposób zapis posłużył do pomiarów długości korzeni i koleoptyli jęczmienia jarego z wykorzystaniem programu analizy obrazu „Image Tools”. Następnie określono świeżą masę korzeni i koleoptyli zboża. Dokładny sposób przeprowadzania mikrobiotestu został opisany w standardowej procedurze operacyjnej (Phytotoxkit 2004). Uzyskane wyniki badań poddano obróbce statystycznej w programie ARM 8.

\section{Wyniki i dyskusja / Results and discussion}

\section{Wpływ E. crus-galli na kiełkowanie oraz wybrane cechy biometryczne jęczmienia jarego}

Chwastnica jednostronna (E. crus-galli) jest jednorocznym, ciepłolubnym chwastem występującym głównie w kukurydzy, roślinach okopowych oraz zbożach jarych. Jedna roślina wytwarza średnio od 200 do 500 diaspor (maksymalnie 1000) zdolnych do kiełkowania w glebie przez okres kolejnych 5 lat (Aldrich 1997; Woźnica 2008). W literaturze światowej wymieniana jest jako groźny chwast $\mathrm{w}$ uprawach, co uzasadnia podejmowanie badań w celu identyfikacji substancji allelopatycznych wytwarzanych przez E. crus-galli i określenia ich wpływu na rośliny uprawne (de Albuquerque i wsp. 2011; Esmaeili i wsp. 2012; Heidarzade i wsp. 2012). Khanh i wsp. (2008) wyizolowali 18 związków należących do terpenów, pochodnych kwasu cynamonowego, kwas ferulowy, kwasy thuszczowe o długim łańcuchu i steroidy. Ponadto Esmaeili 
i wsp. (2012) w ekstraktach z różnych części roślin E. crus-galli, oznaczyli zawartość takich kwasów fenolowych, jak: p-hydroksy benzoesowy, p-kumarynowy, m-kumarynowy, cynamonowy, waniliowy i ferulowy. Najwyższe stężenie tych związków odnotowali w ekstrakcie z liści (17,0 mg/l), natomiast minimalne stężenie otrzymali w roztworze ekstraktu z łupin nasion $(3,35 \mathrm{mg} / \mathrm{l})$.

Przeprowadzone badania wykazały, że bliska obecność ziarniaków E. crus-galli nie wpływała istotnie na zdolność oraz dynamikę kiełkowania jęczmienia jarego odmiany Conchita (tab. 1). Po 48 h zauważono jedynie niewielkie opóźnienie w kiełkowaniu jęczmienia jarego na obiektach o zagęszczeniu 10 i 20 ziarniaków E. crus-galli, niemniej jednak w porównaniu do obiektu kontrolnego nie była to różnica istotna statystycznie. Po 96 h od momentu założenia biotestu, kiełkowanie ziarniaków jęczmienia jarego było bardzo wysokie i zawierało się w przedziale od 98 do100\% (tab. 1).

W badaniach własnych oceniano również długość i świeżą masę korzeni jęczmienia jarego wystawionych na bliskie oddziaływanie zróżnicowanej liczby ziarniaków E. crus-galli. Jedynie na obiekcie o najmniejszym zagęszczeniu ziarniaków E. crus-galli (5 szt./ziarniak jęczmienia jarego) obserwowano zwiększenie świeżej masy i długości korzeni, które jednak nie zostało udowodnione statystycznie w odniesieniu do kontroli. Na obiektach, na których wysiewano 10 sztuk ziarniaków E. crus-galli na 1 ziarniak jęczmienia jarego uzyskano nieistotną statystycznie redukcję długości i masy korzeni. Istotne statystycznie skrócenie korzeni jęczmienia jarego (o 13,5\%) w porównaniu do kontroli, nastąpiło tylko na obiekcie o największej liczbie ziarniaków E. crus-galli (20 szt./ziarniak jęczmienia jarego). Masa korzeni na tym obiekcie została zredukowana o $20,5 \%$ w porównaniu do kontroli, jednak nie była to różnica statystycznie istotna (tab. 1).

Wpływ nasion E. crus-galli na długość i świeżą masę koleoptyli jęczmienia jarego zróżnicowany był w zależności od liczby nasion chwastu przypadających na ziarniak zboża. Efekt stymulujący długość i świeżą masę koleoptyli uzyskano na obiekcie o najmniejszym zagęszczeniu E. crus-galli (5 szt./ziarniak jęczmienia jarego). Różnice te były statystycznie nieistotne. Istotne skrócenie koleoptyli (o 17,1 i $22,0 \% \mathrm{w}$ porównaniu do kontroli) obserwowane na obiektach odpowiednio z 10 i 20 ziarniakami E. crus-galli, potwierdzone zostało $\mathrm{w}$ analizie statystycznej. Przy największym zagęszczeniu ziarniaków E. crus-galli obserwowano również istotne zmniejszenie świeżej masy koleoptyli w porównaniu do obiektu kontrolnego (tab. 1)

\section{Wpływ S. pumila na kiełkowanie oraz wybrane cechy biometryczne jęczmienia jarego}

Włośnica sina (S. pumila) jest trawą jednoroczną, kiełkującą późną wiosną, zachwaszczającą głównie kukurydzę, buraki, a rzadziej zboża jare. Jedna roślina $S$. pumila jest w stanie wytworzyć w ciągu sezonu wegetacyjnego około 200-400 nasion (Aldrich 1997; Woźnica 2008). Jak wskazują doniesienia literaturowe dotyczące zachwaszczenia zbóż jarych w gospodarstwach ekologicznych, gatunek ten jest najczęściej występującym chwastem jednoliściennym, zaraz po E. crus-galli (Staniak i wsp. 2013).

W przeprowadzonych badaniach stwierdzono, że obecność diaspor $S$. pumila nie wpływała istotnie na zdolność kiełkowania jęczmienia jarego odmiany Conchita (niezależnie od liczby ziarniaków S. pumila). Na wszystkich badanych obiektach, po 96 h od momentu założenia doświadczenia, wschody rośliny uprawnej wynosiły 99-100\% (tab. 2).

Jedynie na obiekcie o najmniejszym zagęszczeniu S. pumila (5 szt./ziarniak jęczmienia jarego) odnotowano stymulujące działanie, powodujące zwiększenie świeżej masy (o 15,4\%) i długości korzeni (o 7,1\%), które jednak w odniesieniu do kontroli nie zostało potwierdzone statystycznie. Zwiększenie liczby ziarniaków S. pumila do 10 szt./ziarniak jęczmienia jarego spowodowało natomiast

Tabela 1. Wpływ Echinochloa crus-galli na kiełkowanie i początkowy wzrost jęczmienia jarego Table 1. Influence of Echinochloa crus-galli on germination and initial growth of spring barley

\begin{tabular}{|c|c|c|c|c|c|c|c|c|}
\hline \multirow{2}{*}{$\begin{array}{c}\text { Liczba ziarniaków } \\
\text { Echinochloa crus-galli } \\
\text { [szt.] } \\
\text { No. of Echinochloa } \\
\text { crus-galli kernels } \\
\text { [pcs] }\end{array}$} & \multicolumn{4}{|c|}{$\begin{array}{c}\% \text { skiełkowanych nasion } \\
\text { jęczmienia jarego } \\
\text { Seed germination of spring barley } \\
\text { in } \%\end{array}$} & \multirow[t]{2}{*}{$\begin{array}{l}\text { Długość } \\
\text { korzeni } \\
\text { Root length } \\
{[\mathrm{mm}]}\end{array}$} & \multirow{2}{*}{$\begin{array}{c}\text { Świeża masa } \\
\text { korzeni } \\
\text { Root fresh } \\
\text { weight } \\
{[\mathrm{g}]}\end{array}$} & \multirow{2}{*}{$\begin{array}{c}\text { Długość } \\
\text { koleoptyla } \\
\text { Coleoptyl } \\
\text { length } \\
\text { [mm] }\end{array}$} & \multirow{2}{*}{$\begin{array}{l}\text { Świeża masa } \\
\text { koleoptyla } \\
\text { Coleoptyl fresh } \\
\text { weight } \\
{[\mathrm{g}]}\end{array}$} \\
\hline & $24 \mathrm{~h}$ & $48 \mathrm{~h}$ & $72 \mathrm{~h}$ & $96 \mathrm{~h}$ & & & & \\
\hline 0 & 0 & 99 & 100 & 100 & 74,96 & 0,039 & 37,96 & 0,041 \\
\hline 5 & 0 & 99 & 100 & 100 & 79,74 & 0,044 & 42,85 & 0,049 \\
\hline 10 & 0 & 87 & 98 & 98 & 69,17 & 0,031 & 31,47 & 0,033 \\
\hline 20 & 0 & 91 & 97 & 100 & 64,86 & 0,031 & 29,64 & 0,028 \\
\hline $\begin{array}{l}\operatorname{NIR}(0,05) \\
\operatorname{LSD}(0.05)\end{array}$ & - & 17,90 & 17,30 & 12,20 & 8,021 & 0,0066 & 5,088 & 0,0083 \\
\hline
\end{tabular}


nieistotną statystycznie redukcję długości oraz świeżej masy korzeni. Natomiast istotne statystycznie skrócenie korzeni jęczmienia jarego (o 8,5\%) nastąpiło tylko na obiekcie o największej liczbie ziarniaków S. pumila (20 szt./ziarniak jęczmienia jarego). Takie zagęszczenie diaspor S. pumila spowodowało redukcję świeżej masy korzeni jęczmienia jarego o 15,4\%, jednak różnica ta w porównaniu do obiektu kontrolnego była statystycznie nieistotna (tab. 2).

Długość i świeża masa koleoptyli jęczmienia jarego były różnicowane w zależności od liczby ziarniaków S. pumila. Stymulujące działanie uzyskano w odniesieniu do długości (zwiększenie o 13,8\%) i świeżej masy koleoptyli (24,4\%) jedynie na obiekcie o najmniejszym zagęszczeniu S. pumila (5 szt./ziarniak jęczmienia jarego). Uzyskane różnice $\mathrm{w}$ długości oraz świeżej masie koleoptyli zostały udowodnione statystycznie, zarówno w porównaniu do obiektu kontrolnego, jak i obiektów z 10 i 20 sztukami ziarniaków S. pumila. Zwiększenie zagęszczenia S. pumila do 10 szt./ziarniak jęczmienia jarego spowodowało redukcję świeżej masy i długości koleoptyli, jednak w porównaniu do obiektu kontrolnego, różnice te były statystycznie nieistotne. Jedynie obecność 20 sztuk ziarniaków $S$. pumila przypadających na 1 ziarniak jęczmienia jarego spowodowała istotne zmniejszenie długości koleoptyla w porównaniu do obiektu kontrolnego. Takie zagęszczenie nasion nie wpłynęło istotnie na redukcję świeżej masy koleoptyli (tab. 2).

\section{Wpływ $A$. fatua na kiełkowanie oraz wybrane cechy biometryczne jęczmienia jarego}

Owies głuchy (A. fatua) jest częstym chwastem jednoliściennym, o dużej szkodliwości głównie w zbożach jarych. Jest to jednoroczna roślina, blisko spokrewniona $\mathrm{z}$ owsem siewnym, wytwarzająca 100-200 nasion zachowujących zdolność do kiełkowania przez okres kolejnych 3-10 lat (Aldrich 1997; Woźnica 2008). W strefie okołokorzeniowej roślin $A$. fatua zidentyfikowano kilka różnych związków, które wykazują właściwości allelopatyczne. Są to głównie takie kwasy, jak: p-kumarynowy, waniliowy, 4-hydroksy-

Tabela 2. Wpływ Setaria pumila na kiełkowanie i początkowy wzrost jęczmienia jarego Table 2. Influence of Setaria pumila on germination and initial growth of spring barley

\begin{tabular}{|c|c|c|c|c|c|c|c|c|}
\hline \multirow{2}{*}{$\begin{array}{c}\text { Liczba ziarniaków } \\
\text { Setaria pumila } \\
\text { [szt.] } \\
\text { No. of Setaria pumila } \\
\text { kernels } \\
\text { [pcs] }\end{array}$} & \multicolumn{4}{|c|}{$\begin{array}{c}\text { \% skiełkowanych nasion } \\
\text { jęczmienia jarego } \\
\text { Seed germination of spring barley } \\
\text { in } \%\end{array}$} & \multirow[t]{2}{*}{$\begin{array}{c}\text { Długość } \\
\text { korzeni } \\
\text { Root length } \\
{[\mathrm{mm}]}\end{array}$} & \multirow{2}{*}{$\begin{array}{l}\text { Świeża masa } \\
\text { korzeni } \\
\text { Root fresh } \\
\text { weight } \\
{[\mathrm{g}]}\end{array}$} & \multirow{2}{*}{$\begin{array}{l}\text { Długość } \\
\text { koleoptyla } \\
\text { Coleoptyl } \\
\text { length } \\
\text { [mm] }\end{array}$} & \multirow{2}{*}{$\begin{array}{l}\text { Świeża masa } \\
\text { koleoptyla } \\
\text { Coleoptyl fresh } \\
\text { weight } \\
\text { [g] }\end{array}$} \\
\hline & $24 \mathrm{~h}$ & $48 \mathrm{~h}$ & $72 \mathrm{~h}$ & $96 \mathrm{~h}$ & & & & \\
\hline 0 & 0 & 99 & 100 & 100 & 73,29 & 0,039 & 38,58 & 0,041 \\
\hline 5 & 0 & 100 & 100 & 100 & 78,52 & 0,045 & 43,89 & 0,051 \\
\hline 10 & 0 & 85 & 99 & 99 & 71,46 & 0,033 & 34,10 & 0,037 \\
\hline 20 & 0 & 98 & 99 & 99 & 67,05 & 0,033 & 33,31 & 0,037 \\
\hline $\begin{array}{l}\text { NIR }(0,05) \\
\operatorname{LSD}(0.05)\end{array}$ & - & 17,10 & 13,50 & 13,50 & 5,937 & 0,0076 & 5,111 & 0,0074 \\
\hline
\end{tabular}

Tabela 3. Wpływ Avena fatua na kiełkowanie i początkowy wzrost jęczmienia jarego Table 3. Influence of Avena fatua on germination and initial growth of spring barley

\begin{tabular}{|c|c|c|c|c|c|c|c|c|}
\hline \multirow{2}{*}{$\begin{array}{l}\text { Liczba ziarniaków } \\
\text { Avena fatua } \\
\text { [szt.] } \\
\text { No. of Avena fatua } \\
\text { kernels } \\
\text { [pcs] }\end{array}$} & \multicolumn{4}{|c|}{$\begin{array}{c}\text { \% skiełkowanych nasion } \\
\text { jęczmienia jarego } \\
\text { Seed germination of spring barley } \\
\text { in \% }\end{array}$} & \multirow[t]{2}{*}{$\begin{array}{l}\text { Długość } \\
\text { korzeni } \\
\text { Root length } \\
{[\mathrm{mm}]}\end{array}$} & \multirow{2}{*}{$\begin{array}{c}\text { Świeża masa } \\
\text { korzeni } \\
\text { Root fresh } \\
\text { weight } \\
{[\mathrm{g}]}\end{array}$} & \multirow{2}{*}{$\begin{array}{c}\text { Długość } \\
\text { koleoptyla } \\
\text { Coleoptyl } \\
\text { length } \\
{[\mathrm{mm}]}\end{array}$} & \multirow{2}{*}{$\begin{array}{c}\text { Świeża masa } \\
\text { koleoptyla } \\
\text { Coleoptyl fresh } \\
\text { weight } \\
\text { [g] }\end{array}$} \\
\hline & $24 \mathrm{~h}$ & $48 \mathrm{~h}$ & $72 \mathrm{~h}$ & $96 \mathrm{~h}$ & & & & \\
\hline 0 & 0 & 100 & 100 & 100 & 77,12 & 0,041 & 42,15 & 0,045 \\
\hline 2 & 0 & 97 & 100 & 100 & 71,76 & 0,042 & 37,79 & 0,044 \\
\hline 3 & 0 & 85 & 94 & 94 & 65,13 & 0,032 & 29,95 & 0,030 \\
\hline 5 & 0 & 75 & 98 & 100 & 61,44 & 0,026 & 28,10 & 0,025 \\
\hline $\begin{array}{l}\text { NIR }(0,05) \\
\operatorname{LSD}(0.05)\end{array}$ & - & 9,80 & 15,70 & 12,20 & 4,944 & 0,0079 & 7,246 & 0,0097 \\
\hline
\end{tabular}


benzoesowy, galusowy i ferulowy (Fragasso i wsp. 2012; Iannucci i wsp. 2012).

Badania własne dotyczące zdolności kiełkowania jęczmienia jarego w obecności zróżnicowanej liczby ziarniaków $A$. fatua dowiodły, że po 48 h od momentu wysiewu, liczba skiełkowanych ziarniaków jęczmienia jarego była istotnie niższa na obiektach z 3 i 5 ziarniakami A. fatua w porównaniu do obiektu kontrolnego. Natomiast w momencie zakończenia biotestu (po 96 h), liczba skiełkowanych ziarniaków jęczmienia jarego na obiektach badanych osiągnęła poziom porównywalny do liczby ziarniaków jęczmienia jarego na obiekcie kontrolnym (tab. 3).

Jęczmień jary zareagował statystycznie istotnym skróceniem długości korzeni niezależnie od liczby ziarniaków $A$. fatua. Już w obecności 2 sztuk ziarniaków owsa głuchego przypadających na 1 ziarniak jęczmienia jarego, nastąpiła redukcja długości korzeni o 6,9\%, a zagęszczenie 3 ziarniaków $A$. fatua spowodowało skrócenie korzeni o 15,5\%. Najsilniejszą redukcję długości korzenia rośliny uprawnej (o 20,3\%) uzyskano na obiektach, na których wysiano po 5 sztuk ziarniaków owsa/1 ziarniak jęczmienia jarego. Również masa korzeni jęczmienia jarego była uzależniona od liczby ziarniaków $A$. fatua. Statystycznie istotne różnice uzyskano na obiektach z 3 i 5 sztukami ziarniaków A. fatua. Redukcja masy korzeni na tych obiektach wynosiła odpowiednio o 21,9 i $36,6 \%$ w porównaniu do kontroli (tab. 3).

Kolejne dwie badane cechy czyli długość i świeża masa koleptyli również były zależne od liczby ziarniaków $A$. fatua przypadających na ziarniak jęczmienia jarego. Redukcja długości i świeżej masy koleoptyli została stwierdzona dla wszystkich badanych wariantów, jednak tylko na obiektach z 3 i 5 ziarniakami A. fatua/ziarniak jęczmienia jarego uzyskane różnice zostały potwierdzone statystycznie. W porównaniu do obiektu kontrolnego, długość koleoptyli została zredukowana odpowiednio o 28,9 i 33,3\%, natomiast świeża masa koleoptyli o 33,3 i 44,4\% (tab. 3).

Chemiczne interakcje pomiędzy roślinami wyższymi są od wielu lat tematem licznych badań naukowych (Alam i wsp. 2001; Khalid i wsp. 2002; Gniazdowska i wsp. 2004; Leszczyńska i Grabiński 2004; Willenborg i wsp. 2005; Khan i wsp. 2010; Marczewska-Kolasa i wsp. 2010; Son i wsp. 2010; Khalaj i wsp. 2013).

Zdaniem Heidarzade i wsp. (2012) substancje allelochemiczne uwalniane $\mathrm{z}$ różnych organów chwastów w wyniku działania różnorodnych procesów fizyko-biochemicznych, mogą wpływać w sposób inhibicyjny lub stymulujący na wzrost i rozwój rośliny uprawnej. Większy potencjał allelopatyczny przypisuje się zazwyczaj gatunkom dwuliściennym, jednak nie brakuje również doniesień literaturowych o inhibicyjnym wpływie gatunków jednoliściennych na inne rośliny (Khanh i wsp. 2008; Esmaeili i wsp. 2012). Z badań przeprowadzonych przez
Tantiado i Saylo (2012) wynika, że ekstrakty z wybranych gatunków traw, tj. Chloris barbata, Eleusine indica i Saccharum spontaneum, ograniczały wyraźnie wschody Lactuca sativa. Natomiast inni autorzy podkreślają równie istotne znaczenie nasion chwastów jedno- i dwuliściennych jako potencjalnych źródeł allelopatyn wykazujących działanie inhibicyjne w odniesieniu do kiełkowania i początkowego rozwoju niektórych gatunków roślin uprawnych (Suman i wsp. 2002; Majchrzak 2007; Ghafarbi i wsp. 2012).

Wyniki badań własnych wykazały zróżnicowane oddziaływanie E. crus-galli, S. pumila i A. fatua na kiełkowanie i początkowy wzrost jęczmienia jarego odmiany Conchita. W przypadku ziarniaków S. pumila i E. crus-galli (na obiektach o zagęszczeniu 5 szt. ziarniaków/1 ziarniak jęczmienia jarego) stwierdzono wręcz stymulujące działanie na początkowy wzrost rośliny akceptorowej. Natomiast wyniki uzyskane dla $S$. pumila i E. crus-galli przy ilości 20 sztuk ziarniaków świadczą o potencjale inhibicyjnym diaspor tego donora w odniesieniu do długości korzeni i koleoptyli jęczmienia jarego. Najsilniejsze oddziaływanie na początkowy wzrost jęczmienia jarego miały ziarniaki A. fatua, które wpływały inhibicyjnie na początkowy wzrost i świeżą masę roślin jęczmienia jarego. Zbliżone wyniki badań uzyskał Majchrzak (2007), który wykazał, że obecność ziarniaków $A$. fatua bardzo wyraźnie hamuje długość koleoptyli i korzeni pszenicy ozimej.

\section{Wnioski / Conclusions}

1. Z przeprowadzonych badań wynika, że bliskie sąsiedztwo ziarniaków E. crus-galli, S. pumila i A. fatua nie wpływało w sposób istotny na zdolność kiełkowania ziarniaków jęczmienia jarego, obserwowaną po $96 \mathrm{~h}$. Jedynie w początkowym okresie obserwacji (po $48 \mathrm{~h}$ ) zauważono istotne hamowanie kiełkowania jęczmienia jarego na obiektach z 3 i 5 sztukami ziarniaków A. fatua.

2. Obecność 20 ziarniaków E. crus-galli przypadających na 1 ziarniak jęczmienia powodowała istotną redukcję długości korzeni i koleoptyli jęczmienia jarego.

3. Stymulacyjny wpływ ziarniaków S. pumila i E. crus-galli na świeżą masę korzeni oraz długość i świeżą masę koleoptyla jęczmienia jarego stwierdzono przy najmniejszym zagęszczeniu (5 szt./ziarniak jęczmienia jarego). Jednak tylko w przypadku $S$. pumila stymulacja ta została udowodniona statystycznie.

4. Najsilniejszy inhibicyjny wpływ na początkowy wzrost jęczmienia jarego wykazano dla ziarniaków A. fatua, gdyż już 2 szt./ziarniak jęczmienia jarego powodowały redukcję długości korzeni. Zwiększenie liczby ziarniaków A. fatua wpłynęło na istotne zahamowanie długości i świeżej masy zarówno korzeni, jak i koleoptyli jęczmienia jarego. 


\section{Literatura / References}

Alam S.M., Ala S.A., Azmi A.R., Khan M.A., Ansari R. 2001. Allelopathy and its role in agriculture. Journal of Biological Sciences 1 (5): 308-315. DOI: 10.3923/jbs.2001.308.315.y.

Aldrich R.J. 1997. Ekologia chwastów w roślinach uprawnych. Podstawy zwalczania chwastów. Towarzystwo Chemii i Inżynierii Ekologicznej, Opole, 461 ss. ISBN 83-905669-4-X.

Bhadoria P.B.S. 2011. Allelopathy: A natural way towards weed management. American Journal of Experimental Agriculture 1 (1): 7-20.

de Albuquerque M.B., dos Santos R.C., Lima L.M., de Albuquerque Melo Filho P., Mansur Custódio Nogueira R.J., Gomes da Camara C.A., de Rezende Ramos A. 2011. Allelopathy, an alternative tool to improve cropping systems. A review. Agronomy for Sustainable Development 31: 379-395. DOI: 10.1051/agro/2010031.

Esmaeili M., Heidarzade A., Pirdashti H., Esmaeili F. 2012. Phytotoxic activity of barnyardgrass (Echinochloa crus-galli) on some rice (Oryza sativa) genotypes. International Journal of Agriculture and Crop Sciences 4 (6): 293-297.

Fragasso M., Platani C., Miullo V., Papa R., Iannucci A. 2012. A bioassay to evaluate plant responses to the allelopathic potential of rhizosphere soil of wild oat (Avena fatua L.). Agrochimica 56 (2): 120-128.

Ghafarbi S.P., Hassannejad S., Lotfi R. 2012. Seed to seed allelopathic effects between wheat and weeds. International Journal of Agriculture and Crop Sciences 4 (22): 1660-1665.

Gniazdowska A., Oracz K., Bogatek R. 2004. Allelopatia - nowe interpretacje oddziaływań pomiędzy roślinami. Kosmos - Problemy Nauk Biologicznych 53 (2): 207-217.

Heidarzade A., Esmaeili M., Pirdashti H. 2012. Common allelochemicals in root exudates of Barnyardgrass (Echinochloa crus-galli L.) and inhibitory potential against rice (Oryza sativa) cultivars. International Research Journal of Applied and Basic Sciences 3 (1): 11-17.

Iannucci A., Fragasso M., Platani C., Narducci A., Miullo V., Papa R. 2012. Dynamics of release of allelochemical compounds from roots of wild oat (Avena fatua L.). Agrochimica 56 (3): 185-192.

Jabran K., Farooq M., Hussain M., Hafeez-ur-Rehman, Ali M.A. 2010. Wild oat (Avena fatua L.) and canary grass (Phalaris minor Ritz.) management through allelopathy. [Zwalczanie Avena fatua L. i Phalaris minor Ritz. przy wykorzystaniu allelopatii]. Journal of Plant Protection Research 50 (1): 41-44. DOI: 10.2478/v10045-010-0007-3.

Khalaj M.A., Amiri M., Azimi M.H. 2013. Allelopathy: physiological and sustainable agriculture important aspects. International Journal of Agronomy and Plant Production 4 (5): 950-962.

Khalid S., Ahmad T., Shad R.A. 2002. Use of allelopathy in agriculture. Asian Journal of Plant Sciences 1 (3): 292-297. DOI: 10.3923/ ajps.2002.292.297.

Khan I.A., Hassan G., Marwat K.B., Daur I., Shah S.M.A., Khan N.U., Khan S.A., Hatullah F. 2010. Interaction of wild oat (Avena fatua L.) with divergent wheat cultivars. Pakistan Journal of Botany 42 (2): 1051-1056.

Khanh T.D., Xuan T.D., Chung I.M., Tawata S. 2008. Allelochemicals of barnyardgrass-infested soil and their activities on crops and weeds. Weed Biology and Management 8 (4): 267-275. DOI: 10.1111/j.1445-6664.2008.00300.x.

Kong C.H. 2010. Ecological pest management and control by using allelopathic weeds (Ageratum conyzoides, Ambrosia trifida and Lantana camara) and their allelochemicals in China. Weed Biology and Management 10 (2): 73-80. DOI: 10.1111/j.1445-6664 2010.00373.x.

Leszczyńska D., Grabiński J. 2004. Kiełkowanie zbóż w układach mieszanych - aspekt allelopatyczny. [Cereals germination in mixture stand - allelopathic aspekt]. Annales Univeritatis Mariae Curie-Skłodowska, Sectio E, Agricultura 59 (4): 1977-1984.

Majchrzak L. 2007. Kiełkowanie zbóż w warunkach sąsiedztwa ziarniaków Avena fatua L. i Festuca rubra L. - aspekt allelopatyczny. [Cereals germination in the neighbourhood conditions of grain of Avena fatua L. and Festuca rubra L. - allelopathic aspekt]. Annales Univeritatis Mariae Curie-Skłodowska, Sectio E, Agricultura 62 (2): 185-192.

Marczewska-Kolasa K., Bortniak M., Domaradzki K. 2010. Allelopatyczny wpływ Alopecurus myosuroides na wzrost korzeni pszenicy ozimej. [Allelopathy effect of Alopecurus myosuroides on root growth of winter wheat]. Progress in Plant Protection/Postępy w Ochronie Roślin 50 (2): 820-822.

Narwal S.S., Haouala R. 2011. Allelopathic strategies for ecological weed management. Proceedings of the 3rd International Symposium on Weeds, Sarajevo, 20-21 May, 2011. Herbologia an International Journal on Weed Research and Control 12 (1): 29-56.

Phytotoxkit 2004. Seed germination and early growth microbiotest with higher plants. Standard Operational Procedure. Nazareth, Belgium, MicroBioTest Inc., $31 \mathrm{pp}$.

Sekutowski T. 2010. Alleloherbicydy i bioherbicydy - mit czy rzeczywistość? [Alleloherbicides and bioherbicides - myth or reality?]. Journal of Research and Applications in Agricultural Engineering 55 (4): 84-90.

Son D.H., Thil H.L., Kato-Noguchi H. 2010. Allelopathic potential and isolation process of allelopathic substances in Barnyardgrass (Echinochloa crus-galli). Omonrice 17: 143-146.

Staniak M., Bojarszczuk J., Księżak J. 2013. Zachwaszczenie zbóż jarych uprawianych w siewie czystym i z wsiewką seradeli (Ornithopus sativus L.) w warunkach gospodarstwa ekologicznego. [Weed infestation of spring cereals cultivated in pure sowing and undersown with serradella (Ornithopus sativus L.) in organic farm]. Woda-Środowisko-Obszary Wiejskie 13 (2) (42): 121-131.

Suman A., Shahi H.N., Singh P., Gaur A. 2002. Allelopathic influence of Vinga mungo (black gram) seeds on germination and radical growth of some crop plants. Plant Growth Regulation 38 (1): 69-74. DOI: 10.1023/A:1020943011207.

Tantiado R.G., Saylo M.C. 2012. Allelopathic potential of selected grasses (family Poaceae) on the germination of lettuce seeds (Lactuca sativa). International Journal of Bio-Science and Bio-Technology 4 (2): 27-34.

Vyvyan J.R. 2002. Allelochemicals as leads for new herbicides and agrochemicals. Tetrahedron 58 (9): 1631-1646. DOI: 10.1016/s00404020(02)00052-2.

Willenborg Ch.J., May W.E., Gulden R.H., Lafond G.P., Shirtliffe S.J. 2005. Influence of wild oat (Avena fatua) relative time of emergence and density on cultivated oat yield, wild oat seed production, and wild oat contamination. Weed Science 53 (3): $342-352$. DOI: 10.1614/WS-04-124R1.

Woźnica Z. 2008. Herbologia. Podstawy biologii, ekologii i zwalczania chwastów. Powszechne Wydawnictwo Rolnicze i Leśne, Poznań, 430 ss. ISBN 978-83-09-99007-9. 